\title{
Prediction of biomechanical complications in patients with implant supported fixed dental prostheses in different terms of functional loading
}

\author{
0. M. Doroshenko, O. F. Sirenko \\ Shupyk National Medical Academy of Postgraduate Education, Kyiv, Ukraine
}

Key words:

fixed denta

prostheses,

implants,

masticatory

muscles.

Zaporozhye

medical journal

2017; 19 (4), 424-429

DOI:

10.14739/2310-1210.

2017.4.104923

E-mail:

durektsiya_is@ukr.net,

sirenko_a@ukr.net
Objective - to study features of biomechanical complications (structural fractures, loss of retention, screw loosening/fracture) of implant restorations in different terms of functional loading and work out preventive measures.

Materials and methods. The results of prosthetic treatment with implant supported fixed dental prostheses were analyzed among 65 patients, who were treated between 2011 and 2016. There were 28 (47.1\%) men, 37 women (56.9\%), the average age of patients was $35.6 \pm 12.7$ years. All patients had small defects of dentition in posterior region without severe periodontal or general pathology. Prosthetic treatment was performed on two-staged osteointegrated "root form" implants with a screw design. According to the objective of the study all patients were divided into three groups depending on the period within implant placement and tooth extraction (6-8 month or more than 2 years), the terms of functional loading and usage of protective occlusal splits. The incidence of biomechanical complications and functional activity of masticatory muscles were detected.

Results. The incidence of mechanical complications during 5-year period was 3.85 times higher in patients with long-term existing defects of dentition after tooth extraction and conventional prosthetic treatment with deferred occlusal loading ( 3 cases $(15 \%)$ of loss of retention, 5 cases $(25 \%)$ of veneering material fracture, 1 case $(5 \%)$ of abutment screw loosening and 1 case $(5 \%)$ of abutment screw fracture) in comparison to patients with early functional loading and shorter period after tooth extraction ( 1 case $(4.3 \%)$ of loss of retention and 2 cases $(8.7 \%)$ of veneering material fracture). Protective occlusal splints' application and early functional loading in prosthetic treatment of patients with long-term existing defects of dentition after tooth extraction allowed to decrease the incidence of mechanical complications in 1.57 times in comparison to conventional treatment with deferred loading.

Conclusions. The incidence of biomechanical complications of implant restorations is higher in patients with long-term existing defects of dentition after tooth extraction and deferred occlusal loading in comparison to cases of well-timed prosthetics and early functional loading. Protective occlusal splints are proved as effective preventive measures to decrease the incidence of mechanical complications of implant supported fixed dental prostheses and to induce faster normalization of masticatory activity.
Ключові слова:

незнімні зубні протези, імплантати, жувальні м'язи.

Запорізький медичний журнал. - 2017. T. 19, № 4(103). C. 424-429

\section{Прогнозування біомеханічних ускиаднень у пацієнтів із незнімними зубними протезами на імплантатах при різних термінах функціонального навантаження}

\section{О. М. Аорошенко, О. Ф. Сіренко}

Мета роботи - вивчити особливості виникнення біомеханічних ускладнень (структурних порушень, втрати ретенції, ослаблення/перелому ґвинта) реставрацій на імплантатах при різних термінах функціонального навантаження та розробити заходи профрілактики.

Матеріали та методи. Проаналізовані результати ортопедичного лікування незнімними зубними протезами на імплантатах 65 хворих, які лікувалися з 2011 по 2016 рік. Чоловіків було 28 (47,1\%), жінок- 37 (56,9\%), середній вік-35,6 12,7 року. Усі пацієнти були з малими дефектами зубних рядів у боковій ділянці без вираженої патології пародонта або загальної патології. Ортопедичне лікування здійснювали на двоетапних остеоінтегрованих ґвинтових коренеподібних імплантатах. Згідно з метою роботи, пацієнтів поділили на три групи залежно від періоду між встановленням імплантату та видаленням зуба (6-8 місяців або більше ніж 2 роки), термінів функціонального навантаження та застосування захисних оклюзійних кап. Визначалась частота виникнення біомеханічних ускладнень і функціональна активність жувальних м'язів.

Результати. Частота виникнення механічних ускладнень протягом 5 років була у 3,85 раза вищою в пацієнтів із тривалим періодом відсутності зубів після їх видалення та традиційним протезуванням із відтермінованим оклюзійним навантаженням (3 випадки (15\%) втрати ретенції, 5 випадків (25 \%) сколів облицювального матеріалу, 1 випадок (5 \%) ослаблення ґвинта абатмента, 1 випадок (5 \%) перелому ґвинта абатмента) порівняно з пацієнтами з раннім фуннціональним навантаженням і коротшим періодом після видалення зубів (1 випадок (4,3 \%) втрати ретенції та 2 випадки (8,7 \%) сколів облицювального матеріалу). Застосування захисних оклюзійних кап і раннього функціонального навантаження в пацієнтів із тривалим періодом відсутності зубів після їхнього видалення дало змогу знизити частоту виникнення механічних ускладнень в 1,57 раза порівняно з традиційним лікуванням і відтермінованим навантаженням.

Висновки. Частота виникнення біомеханічних ускладнень реставрацій на імплантатах є вищою в пацієнтів із тривалим періодом відсутності зубів після їхнього видалення та відтермінованим оклюзійним навантаженням порівняно 3 випадками своєчасного протезування та раннього функціонального навантаження. Захисні оклюзійні капи - ефективні профрілактичні засоби для зменшення частоти виникнення механічних ускладнень незнімних зубних протезів з опорою на імплантати та стимулювання швидшої нормалізації активності жувальних м'язів. 


\section{Прогнозирование биомеханических осложнений у пациентов с несъёмными зубными протезами на имплантатах при разных сроках функциональной нагрузки}

\section{Е. Н. Аорошенко, А. Ф. Сиренко}

Цель работы - изучить особенности возникновения биомеханических осложнений (структурных нарушений, потери ретенции, ослабления/перелома винта) реставраций на имплантатах при разных сроках функциональной нагрузки и разработать профилактические меры.

Материалы и методы. Проанализированы результаты ортопедического лечения несъёмными зубными протезами на имплантатах 65 больных, которые проходили лечение с 2011 по 2016 г. Мужчин было 28 (47,1%), женщин - 37 (56,9 \%), средний возраст пациентов $-35,6 \pm 12,7$ года. Все пациенты были с малыми дефеектами зубных рядов в боковом участке без выраженной патологии пародонта или общей патологии. Ортопедическое лечение проводилось на двухэтапных остеоинтегрированных винтовых корневидных имплантатах. Согласно цели работы пациенты были разделены на три группы в зависимости от периода между установкой имплантата и удалением зуба (6-8 месяцев или более 2 лет), сроков функциональной нагрузки и применения защитных окклюзионных капп. Определялась частота возникновения биомеханических осложнений и функциональная активность жевательных мышц.

Результаты. Частота возникновения механических осложнений в течение 5 лет была в 3,85 раза выше у пациентов с длительным периодом отсутствия зубов после их удаления и традиционным протезированием с отсроченной окклюзионной нагрузкой (3 случая (15 \%) потери ретенции, 5 случаев (25 \%) сколов облицовочного материала, 1 случай (5 \%) ослабления винта абатмента, 1 случай (5 \%) перелома винта абатмента) по сравнению с пациентами с ранней функциональной нагрузкой и более коротким периодом после удаления зубов (1 случай (4,3 \%) потери ретенции и 2 случая (8,7 \%) сколов облицовочного материала). Применение защитных окклюзионных капп и ранней функциональной нагрузки у пациентов с длительным периодом отсутствия зубов после их удаления позволило снизить частоту возникновения механических осложнений в 1,57 раза по сравнению с традиционным лечением и отсроченной нагрузкой.

Выводы. Частота возникновения биомеханических осложнений реставраций на имплантатах является более высокой у пациентов с длительным периодом отсутствия зубов после их удаления и отсроченной окклюзионной нагрузкой по сравнению со случаями своевременного протезирования и ранней функциональной нагрузки. Защитные окклюзионные каппы являются эффективными профилактическими средствами для уменьшения частоты возникновения механических осложнений несъёмных зубных протезов с опорой на имплантаты и стимулирования скорейшей нормализации активности жевательных мышц.

\section{Introduction}

Dental rehabilitation has a pivotal role in health care preservation. There is a growing body of literature that recognizes the importance of prosthetic treatment of partially dentate patients to prevent or manage temporomandibular disorders, especially among young and middle-aged patients. Filling the defects of dentition with implant supported dental prostheses is a major area of interest within the field of prosthetic dentistry. Recently, a considerable literature has grown up around the theme of the possibility of long-term implant restorations' suitability in the light of occurrence of different types of complications during the follow-up period, concerning surgical or prosthetic phase of treatment.

Despite their long clinical success, implant supported fixed dental prostheses (FDP) have a number of clinical issues in use. The issue of implant complications has received considerable critical attention. It is now well established from a variety of studies, that implant failures can be divided into early (failure to achieve osteointegration) and late (failure to maintain established osteointegration during functional loading) complications [1-3]. Excessive occlusal stress and bacterial-induced peri-implant bone loss were established as the most common causes of implant failure [3].

A considerable amount of literature has been published on biological implant complications. Implants' mechanical failure upon extended use is seldom mentioned in the literature. Moreover, there is little published data on mechanical integrity of implant supported FDP, as opposed to the socalled "biological" failure [2].
Prosthetic complications can be grouped into categories: veneering material fracture, prosthetic screw loosening, prosthetic screw fracture, implant fracture and framework fracture (Carlson \& Carlsson, 1994, as cited in Gooty, et al., 2014) [4]. To date, there has been no reliable evidence that prosthesis screw fracture was noted almost equally with fixed complete dentures (3\%) and fixed partial dentures (5\%) the mean incidence was $4 \%$ ranging from $0.0 \%$ to $19 \%$ [4]. Though abutment screw fracture is a rare problem, it continues to be a great challenge in restorative practice to remove the fractured screw conservatively [4].

Data from research by Pjetursson et al. (2014), based on clinical studies with 5- and 10-year follow-up periods, stated high frequency of mechanical complications in a 5-year period total rate ranging from $16.3 \%$ to $53.4 \%$, while screw fracture was observed in $9.3 \%$ cases after a 5 -year study and in $18.5 \%$ cases after 10-year use [1].

As it has been previously observed, the least frequent technical complication involved fracture $(0.2 \%)$, loss $(0.4 \%)$ and loosening (3.3\%) of the screw [5]. P. Calderon et al., 2014 reported that the most frequent complications were loss of resin covering the screw $(23.8 \%)$, loss of prostheses retention (18.6\%) and fractures of the resin (12.4\%) [5]. A high frequency of misfit between the prosthesis and abutment $(25.4 \%)$ was found, which was significantly associated $(p<0.05)$ with other variables [5].

Studies over the past two decades have provided important information on possible factors influencing implant fracture. Causal factors leading to implant fracture remain speculative. Nevertheless, the most common of them include
Ключевые слова:

несъёмные

зубные протезы, имплантаты, жевательные мышцы, функциональная нагрузка.

Запорожский медицинский журнал. - 2017. T. 19, № 4(103). C. $424-429$ 
production flaws, misfit of suprastructure, parafunctional status of masticatory muscles (bruxism) or heavy occlusal overload, inadequate implant size and number, progressive bone loss, metal fatigue, and galvanic activity [6].

At present, it is admitted that overloading factors may negatively influence on implant longevity due to large cantilevers, parafunctions, improper occlusal designs, and premature contacts [7]. It was stated that occlusal overload is regarded as one of the main causes for progressive peri-implant bone loss and implant prosthesis failure [7] Biomechanically controlled occlusion within physiologic limit is recognized as optimal way to ensure a long-term implant success [7].

Debate continues about the best strategies for the management of implant restorations' loading concerning main occlusal concepts (balanced, groupfunction, and mutually protected occlusion). Generally accepted occlusal considerations in implant dentistry contemplate following features of prosthetics: bilateral stability in centric occlusion, evenly distributed occlusal contacts and force, absence of interferences between retruded position and centric position, wide freedom in centric (habitual) occlusion, anterior guidance whenever possible, and smooth lateral excursive movements without working/non-working interferences [7].

Kim, Oh, Misch, \& Wang (2004), carrying out fundamental research in implant dentistry, came to the conclusion that systematic, individualized treatment plans and precise surgical/prosthodontic procedures based on biomechanical principles are prerequisites for optimal implant occlusion [7]

Komiyama et al. (2012) confirmed that excess load on a final restoration after successful implant osteointegration is a risk factor for vertical peri-implant bone loss and/or may be deleterious for the suprastructure in implant supported prostheses, which can be especially dangerous in case of occlusal parafunction [8]. Nevertheless, there is no reliable data for correlation between the failures and excessive load of dental implants.

Much uncertainty still exists about the relationship between mechanical implant complications and poor design with abnormally high loads as well as nature and amplitude of masticatory loads and implant stresses [2]. Our previous electromyography (EMG) research of 40 persons with FDP on dental implants, proved that the activity of masticatory muscles depends on the period after tooth extraction and provision of dental implantation, and had faster normalization while using early functional loading, transmitted through provisional prosthetic constructions [9].

The purpose of this investigation was to explore the interrelation of factors: the incidence of biomechanical implant restorations' failure, period after tooth extraction, terms of functional occlusal loading and bioelectrical activity of masticatory muscles for establishment of the range of preventive measures.

\section{Objective}

The specific objective of this study was to study the features of biomechanical complications (structural fractures, loss of retention, screw loosening/fracture) of implant restorations in different terms of functional loading and work out preventive measures.

\section{Materials and methods}

The results of prosthetic treatment with implant supported FDP were analyzed among 65 patients, who were treated between 2011 and 2016 at the Department of Dentistry of the Shupyk National Medical Academy of Postgraduate Education, Kyiv, Ukraine. There were $28(47.1 \%)$ men and $37(56.9 \%)$ women, the average age of patients was $35.6 \pm 12$ years. To minimize an effect of kind, location of prostheses, type of occlusion, type of attachment only patients with posterior single-crown cemented FDP and physiological occlusion were included in this study. All patients had small defects of dentition (1-3 teeth missing) in posterior region. There were no pathology of periodontal tissues and no severe general pathology diagnosed in cured patients. An intraoral examination was performed using a clinical probe and mouth mirror without removing the fixed prostheses. Prosthetic treatment was performed on twostaged osteointegrated "root form" implants with a screw design. Implant stability was checked by frequency-resonance analysis measuring Implant Stability Quotient (ISQ) ("Osstell ISQ") and the level of marginal bone loss was determined radiologically (radiovisiography, computer tomography). Surface EMG was used to evaluate functional activity of masticatory muscles to establish the efficiency of prosthetic treatment by computer neuroelectromyograph "M-Test" (DX Systems, Kharkiv, Ukraine). The bioelectrical activity of the masticatory muscles was determined by electromyographic parameters: average amplitude of voluntary compression (AAVC), average amplitude of mastication (AAM), duration of activity phase (AP), duration of rest phase (RP) and activity/rest phase ratio (K).

The group of control included 10 patients of the same age with intact dental arches and sanified oral cavity.

According to the objective of the study, all patients were divided into three groups.

The first group included 23 patients with dental implant placement after $6-8$ month after tooth extraction. Provisional restorations were placed in 3 month after implant insertion. After 3-month non-functional loading of provisional restorations, they were changed into cemented metalloceramic crowns. No protective occlusal devices were used in these patients.

The second group involved 20 patients with implant placement after more than 2 years after tooth extraction. Conventional placement of cemented metalloceramic functional loaded implant supported restorations was performed in 6 month after implant insertion. No provisional restorations or protective occlusal splits were used.

The third group included 22 patients with implant placement after more than 2 years after tooth extraction. Provisional restorations were placed in 3 month after implant insertion. After 3-month non-functional loading of provisional restorations, they were changed into cemented metalloceramic crowns. Protective occlusal splits were used during the treatment and further follow-up period.

Data for this study were collected using statistical analysis on a personal computer using MS Excel 10 and Statistica 6.0 for Windows (StatSoft Inc, USA). Results were presented as arithmetic average value (M) and the standard error of average meaning $(\mathrm{m})$ using Student's test. Differences between the data were considered valid at level of significance at $p<0.05$. 


\section{Results and discussion}

The results of prosthetic treatment with implant supported fixed dental prostheses were analyzed among 65 patients, who were treated between 2011 and 2016. Mean ISQ values after implant placement of implants were $72.98 \pm 3.04$ and did not differ in all study groups. The measurement during follow-up period ( 6 and 12 months after implant placement) demonstrated similar mean ISQ values in patient of all groups (68.79 \pm 1.94 and $69.88 \pm 2.43$ respectively). Data, obtained by the frequency-resonance analysis, confirmed the success of implant osteointegration and proved the possibility of further prosthetic treatment, likewise stated by other researches [7].

During 6 month after placement of FDP on dental implants, the loss of retention was observed in 2 cases $(10 \%)$ in the second group and 1 case $(4.5 \%)$ in the third group of patients. Veneering material fracture was revealed in 3 cases (15\%) of the second group patients and 1 case $(4.5 \%)$ in the third group. The incidence of all mechanical complications was 2.74 times lower in the third group in comparison to the second group, which can be explained by earlier functional loading and protective occlusal splints' application. There were no mechanical complications observed in the first group of patients.

After 5 -year period 1 case of the loss of retention (4.3\%) and 2 cases of veneering material fracture $(8.7 \%)$ of FDP on implants were detected in the first group of patients with early functional loading and shorter period after tooth extraction. The incidence of mechanical complications during 5-year period was 3.85 times higher in patients of the second group in comparison to the first group. Conventional prosthetic treatment of patients with long-term existing defects of dentition after tooth extraction and deferred occlusal loading in 5-year period resulted in 3 cases (15\%) of loss of retention, 5 cases ( $25 \%$ ) of veneering material fracture, 1 case $(5 \%)$ of abutment screw loosening and 1 case $(5 \%)$ of abutment screw fracture, corresponding to previously obtained data [4].

Protective occlusal splints' application and early functional loading in prosthetic treatment of patients with long-term existing defects of dentition after tooth extraction allowed to decrease the incidence of mechanical complications in 1.57 times in comparison to conventional treatment with deferred loading. After 5 -year period 2 cases $(9.1 \%)$ of loss of retention, 4 cases (18.2 \%) of veneering material fracture and 1 case $(4.5 \%)$ of abutment screw loosening of implant supported FDP were observed in patients of the third group.

Surface EMG was performed before treatment, 6 and 12 month after the placement of dental implants. The record of 3-second voluntary dental compression test in control group revealed high-amplitude vibrations of approximately equal biopotentials and inclusion of large number of motor units. The precise alternation of periods of bioelectrical activity and rest was observed during the mastication test in patients of control group. Gradually rising to the middle of a biopotential, amplitude of vibration descended to its end. The amplitude of mastication was expressed less to the end of mastication with high-amplitude vibrations in the beginning of the test. The duration of activity phase in control group was approximately equal to the period of rest. Insignificant asymmetry was detected in masticatory muscles' activity.

The results of EMG study of bioelectrical activity of masticatory muscles in the first group of patients with early functional loading are presented in Table 1. Before treatment average amplitude of voluntary compression in the first group of patients was $536 \pm 15.2 \mu \mathrm{V}$ and $522 \pm 12.50 \mu \mathrm{V}$ on the right and left sides, respectively, and significantly exceeded analogous parameters of patients with long-term existing defects of dentition after tooth extraction $(p<0.05)$.

Significant discrepancy was detected in electromyographic parameters of masticatory muscles between control group and all three study groups' indices before treatment. On average, amplitude of voluntary compression on the side of the defect of dentition was shown to have lower values among patients of all study groups, but its magnitude differed. The lowest average amplitude of voluntary compression was observed in the second $(426 \pm 12.7 \mu \mathrm{V}$ and $410 \pm 12.1 \mu \mathrm{V}$ on the right and left sides, respectively) (Table 2) and the third $(412 \pm 18.3 \mu \mathrm{V}$ and $408 \pm 11.4 \mu \mathrm{V}$ on the right and left sides, respectively) groups of patients (Table 3 ) in comparison to the control group $(p<0.05)$.

The ratio of activity and rest phase $(K)$ was established in each group with significantly higher coefficients in the second $(1.46 \pm 0.03$ and $1.49 \pm 0.05$ on the right and left sides, respectively) and third ( $1.38 \pm 0.05$ and $1.46 \pm 0.03$ on the right and left sides, respectively) groups in comparison to control group $(p<0.05)$ in the beginning of treatment.

Table 1. Electromyographic parameters of masticatory muscles during prosthetic treatment in the first group of patients $(\mathrm{M} \pm \mathrm{m}, \mathrm{n}=23)$

\begin{tabular}{|c|c|c|c|c|c|}
\hline \multicolumn{2}{|c|}{ Indices, measurement units } & \multirow{2}{*}{$\begin{array}{l}\text { Control group } \\
n=10 \\
649 \pm 12.7\end{array}$} & \multirow{2}{*}{$\begin{array}{l}\text { Before treatment } \\
536 \pm 15.2^{*}\end{array}$} & \multirow{2}{*}{$\begin{array}{l}\text { After } 6 \text { months } \\
586 \pm 13.7\end{array}$} & \multirow{2}{*}{$\begin{array}{l}\text { After } 12 \text { months } \\
625 \pm 13.60\end{array}$} \\
\hline $\operatorname{AAVC}(\mu \mathrm{V})$ & MR & & & & \\
\hline & $M L$ & $612 \pm 14.1$ & $522 \pm 12.50^{*}$ & $568 \pm 12.9$ & $598 \pm 3.70$ \\
\hline \multirow[t]{2}{*}{$\mathrm{AAM}(\mu \mathrm{V})$} & MR & $725 \pm 19.7$ & $590 \pm 4.53^{*}$ & $698 \pm 7.45$ & $711 \pm 13.2$ \\
\hline & $\mathrm{ML}$ & $684 \pm 13.6$ & $581 \pm 2.8^{*}$ & $659 \pm 5.12$ & $696 \pm 11.1$ \\
\hline \multirow[t]{2}{*}{$\mathrm{AP}(\mathrm{ms})$} & MR & $325 \pm 12.7$ & $345 \pm 12.9^{*}$ & $332 \pm 5.23$ & $329 \pm 14.6$ \\
\hline & $\mathrm{ML}$ & $311 \pm 15.2$ & $367 \pm 10.21^{*}$ & $336 \pm 12.1$ & $327 \pm 6.9$ \\
\hline \multirow[t]{2}{*}{$\mathrm{RP}(\mathrm{ms})$} & MR & $302 \pm 5.7$ & $277 \pm 8.1^{*}$ & $290 \pm 3.46$ & $297 \pm 5.3$ \\
\hline & $\mathrm{ML}$ & $294 \pm 12.8$ & $268 \pm 7.12^{*}$ & $286 \pm 12.2$ & $297 \pm 9.3$ \\
\hline \multirow[t]{2}{*}{ K } & MR & $1.08 \pm 0.05$ & $1.25 \pm 0.02^{*}$ & $1.14 \pm 0.05$ & $1.1 \pm 0.09$ \\
\hline & $\mathrm{ML}$ & $1.06 \pm 0.11$ & $1.37 \pm 0.03^{*}$ & $1.17 \pm 0.03$ & $1.1 \pm 0.01$ \\
\hline
\end{tabular}

*: Significant differences from the control group $(p<0.05)$.

AAVC: average amplitude of voluntary compression; AAM: average amplitude of mastication; AP: duration of activity phase; RP: duration of rest phase; K: activity/rest phase ratio; MR: right $\mathrm{m}$. masseter; ML: left $\mathrm{m}$. masseter. 
Table 2. Electromyographic parameters of masticatory muscles during prosthetic treatment in the second group of patients $(M \pm m, n=20)$

\begin{tabular}{|c|c|c|c|c|c|}
\hline \multicolumn{2}{|c|}{ Indices, measurement units } & \multirow{2}{*}{$\begin{array}{l}\text { Control group } \\
n=10\end{array}$} & \multirow{2}{*}{$\begin{array}{l}\text { Before treatment } \\
426 \pm 12.7^{\star}\end{array}$} & \multirow{2}{*}{$\begin{array}{l}\text { After } 6 \text { months } \\
534 \pm 7.89^{*}\end{array}$} & \multirow{2}{*}{$\begin{array}{l}\text { After } 12 \text { months } \\
569 \pm 10.60^{*}\end{array}$} \\
\hline $\operatorname{AAVC}(\mu \mathrm{V})$ & MR & & & & \\
\hline & $\mathrm{ML}$ & $612 \pm 14.1$ & $410 \pm 12.1^{*}$ & $526 \pm 6.70^{*}$ & $546 \pm 12.7^{*}$ \\
\hline \multirow[t]{2}{*}{ AAM $(\mu \mathrm{V})$} & MR & $725 \pm 19.7$ & $459 \pm 9.9^{*}$ & $629 \pm 10.3^{*}$ & $661 \pm 10.5^{*}$ \\
\hline & $\mathrm{ML}$ & $684 \pm 13.6$ & $487 \pm 8.8^{*}$ & $616 \pm 9.5^{*}$ & $655 \pm 11.5^{*}$ \\
\hline \multirow[t]{2}{*}{$\mathrm{AP}(\mathrm{ms})$} & MR & $325 \pm 12.7$ & $375 \pm 9.4^{*}$ & $356 \pm 9.5$ & $339 \pm 12.6$ \\
\hline & $\mathrm{ML}$ & $311 \pm 15.2$ & $383 \pm 10.5^{\star}$ & $349 \pm 8.1$ & $342 \pm 6.5$ \\
\hline \multirow[t]{2}{*}{$\mathrm{RP}(\mathrm{ms})$} & MR & $302 \pm 5.7$ & $256 \pm 9.3^{*}$ & $288 \pm 6.9$ & $299 \pm 11.4$ \\
\hline & $\mathrm{ML}$ & $294 \pm 12.8$ & $256 \pm 6.7^{*}$ & $270 \pm 6.1$ & $289 \pm 6.13$ \\
\hline \multirow[t]{2}{*}{ K } & MR & $1.08 \pm 0.05$ & $1.46 \pm 0.03^{*}$ & $1.24 \pm 0.04$ & $1.13 \pm 0.06$ \\
\hline & $\mathrm{ML}$ & $1.06 \pm 0.11$ & $1.49 \pm 0.05^{*}$ & $1.29 \pm 0.06$ & $1.18 \pm 0.04$ \\
\hline
\end{tabular}

*: significant differences from the control group $(p<0.05)$.

AAVC: average amplitude of voluntary compression; AAM: average amplitude of mastication; AP: duration of activity phase; RP: duration of rest phase; K: activity/rest phase ratio; MR: right $\mathrm{m}$. masseter; ML: left $\mathrm{m}$. masseter.

Table 3. Electromyographic parameters of masticatory muscles during prosthetic treatment in the third group of patients $(M \pm m, n=22)$

\begin{tabular}{|c|c|c|c|c|c|}
\hline \multicolumn{2}{|c|}{ Indices, measurement units } & \multirow{2}{*}{$\begin{array}{l}\text { Control group } \\
n=10\end{array}$} & \multirow{2}{*}{$\begin{array}{l}\text { Before treatment } \\
412 \pm 18.3^{*}\end{array}$} & \multirow{2}{*}{$\begin{array}{l}\text { After } 6 \text { months } \\
552 \pm 9.12^{*}\end{array}$} & \multirow{2}{*}{$\begin{array}{l}\text { After } 12 \text { months } \\
587 \pm 13.5^{\star}\end{array}$} \\
\hline $\operatorname{AAVC}(\mu \mathrm{V})$ & MR & & & & \\
\hline & $\mathrm{ML}$ & $612 \pm 14.1$ & $408 \pm 11.4^{*}$ & $561 \pm 10.70^{*}$ & $573 \pm 12.8^{*}$ \\
\hline \multirow[t]{2}{*}{$\mathrm{AAM}(\mu \mathrm{V})$} & MR & $725 \pm 19.7$ & $477 \pm 13.9^{*}$ & $647 \pm 12.8^{*}$ & $699 \pm 7.4$ \\
\hline & $\mathrm{ML}$ & $684 \pm 13.6$ & $491 \pm 12.8^{*}$ & $634 \pm 10.5^{*}$ & $664 \pm 5.12$ \\
\hline $\mathrm{AP}(\mathrm{ms})$ & MR & $325 \pm 12.7$ & $368 \pm 10.4^{*}$ & $343 \pm 9.5$ & $332 \pm 5.23$ \\
\hline \multirow[t]{2}{*}{$\mathrm{RP}(\mathrm{ms})$} & MR & $302 \pm 5.7$ & $266 \pm 4.11^{*}$ & $291 \pm 4.9$ & $295 \pm 3.46$ \\
\hline & $\mathrm{ML}$ & $294 \pm 12.8$ & $258 \pm 2.12^{*}$ & $285 \pm 7.2$ & $291 \pm 12.2$ \\
\hline \multirow[t]{2}{*}{ K } & MR & $1.08 \pm 0.05$ & $1.38 \pm 0.05^{*}$ & $1.17 \pm 0.04$ & $1.13 \pm 0.05$ \\
\hline & $\mathrm{ML}$ & $1.06 \pm 0.11$ & $1.46 \pm 0.03^{*}$ & $1.19 \pm 0.03$ & $1.15 \pm 0.06$ \\
\hline
\end{tabular}

*: significant differences from the control group $(p<0.05)$.

AAVC: average amplitude of voluntary compression; AAM: average amplitude of mastication; AP: duration of activity phase; RP: duration of rest phase; K: activity/rest phase ratio; MR: right $\mathrm{m}$. masseter; ML: left $\mathrm{m}$. masseter.

The results, as shown in Table 1, indicate that all electromyographical parameters of bioelectrical activity of masticatory muscles in the first group had strong tendency to normalization during all period of prosthetic treatment and nearly approached the values of control group in 12 months after implant placement. Such results correspond with previously obtained data [9] and can be explained by influence of early terms of functional loading and shorter period after tooth extraction.

During early follow-up period (6 month after implant placement) mean values of bioelectrical activity of masticatory muscles were higher in the third group of patients (AAVC: $552 \pm 9.12 \mu \mathrm{V}$ and $561 \pm 10.70 \mu \mathrm{V}$ on the right and left sides, respectively; AAM: $647 \pm 12.8 \mu \mathrm{V}$ and $634 \pm 10.5 \mu \mathrm{V}$ on the right and left sides, respectively) in comparison to the second group (AAVC: $534 \pm 7.8912 \mu \mathrm{V}$ and $526 \pm 6.70 \mu \mathrm{V}$ on the right and left sides, respectively; AAM: $629 \pm 10.3 \mu \mathrm{V}$ and $616 \pm 9.5 \mu \mathrm{V}$ on the right and left sides, respectively) $(p<0.05)$. During this period the ratio of activity and rest phase $(K)$ descended faster in the third group of patients $(1.17 \pm 0.04$ and $1.19 \pm 0.03$ on the right and left sides, respectively) in comparison to the second group (1.24 \pm 0.04 and $1.29 \pm 0.06$ on the right and left sides, respectively) $(p<0.05)$. Faster normalization of electromyographical parameters and reduction of asymmetry in masticatory muscles' activity in the third group corresponds to the lower incidence of biomechanical complications during early follow-up period and can be explained by earlier functional loading and protective occlusal splints' application in comparison to the second group with deferred prosthetics.

Further analysis showed that normalization of bioelectrical activity of masticatory muscles in the second $(569 \pm 10.60 \mu \mathrm{V}$ and $546 \pm 12.7 \mu \mathrm{V}$ on the right and left sides, respectively) and the third ( $587 \pm 13.5 \mu \mathrm{V}$ and $573 \pm 12.8 \mu \mathrm{V}$ on the right and left sides, respectively) groups was slower in comparison to the patients of the first group $(p<0.05)$, but did not have significant difference among themselves $(p>0.05)$. The same tendency was observed in changes of activity/rest phase ratio in the second (Table 2) and the third (Table 3) groups with slower decrease of muscles activity asymmetry in comparison to the patients of the first group $(p<0.05)$. Obtained EMG data corresponds to previous study results $[9,10]$.

\section{Conclusions}

1. The incidence of biomechanical complications (structural fractures, loss of retention, screw loosening/ fracture) of implant restorations is 3.85 times higher in patients with long-term existing defects of dentition after tooth extraction with deferred occlusal loading than in case of welltimed prosthetics and early functional loading.

2. Mechanical implant restorations' failures are associated with unfavourable loading directions and excessive occlusal loading as a result of poorly planned occlusion with lateral friction between the occlusal surfaces and inadequate design of implant supported fixed dental prostheses 
rather than with the growing activity of masticatory muscles. Total rate of mechanical complications was higher in patients with deferred occlusal loading (50.0\%) than in case of early functional loading and well-timed prosthetics (13.0\%) during follow-up period.

3. Protective occlusal splints are proved as effective preventive measures to decrease the incidence of mechanical complications of implant supported fixed dental prostheses during follow-up period more than in 1.57 times and to induce faster normalization of masticatory activity in case of longterm existing defects of dentition after tooth extraction (total mechanical failure rate during follow-up period was $50 \%$ and $31.8 \%$ respectively).

4. Stability of masticatory system, well-timed prosthetics and balanced occlusal force distribution are key factors in prevention of mechanical implant prostheses complications.

Perspective of further scientific researches: study of material-related factors in prosthetic complications on dental implants and application of digital technology for final restorations' design and production.

\section{References}

[1] Pjetursson, B. E., Asgeirsson, A. G., Zwahlen, M., \& Sailer, I. (2014). Improvements in Implant Dentistry over the Last Decade: Comparison of Survival and Complication Rates in Older and Newer Publications. The International Journal Of Oral \& Maxillofacial Implants, 29, 308-324. doi: 10.11607/jomi.2014suppl.g5.2.

[2] Shemtov-Yona, K., \& Rittel, D. (2015). An Overview of the Mechanical Integrity of Dental Implants. BioMed Research International, 2015 547384. http://doi.org/10.1155/2015/547384

[3] Shnaiderman-Shapiro, A., Dayan, D., Buchner, A., Schwartz, I., Yahaom, R., \& Vered, M. (2015). Histopathological Spectrum of Bone Lesions Associated with Dental Implant Failure: Osteomyelitis and Beyond. Head and Neck Pathology, 9(1), 140-146. doi: 10.1007/s12105-014-0538-4

[4] Gooty, J. R., Palakuru, S. K., Guntakalla, V. R., \& Nera, M. (2014). Noninvasive method for retrieval of broken dental implant abutment screw. Contemporary Clinical Dentistry, 5(2), 264-267. doi: 10.4103/0976237X.132382.

[5] Calderon, P. S. Dantas, P. M. Montenegro, S. C. Carreiro, A. F. Oliveira, A. G., Dantas, E. M., \& Gurgel, B. C. (2014). Technical complications with implant-supported dental prostheses. Journal of Oral Science, 56(2), 179-184. http://doi.org/10.2334/josnusd.56.179.

[6] Han, H., Kim, S., \& Han, D. (2014) Multifactorial evaluation of implant failure: A 19-year retrospective study. International Journal of Oral \& Maxillofacial Implants, 29, 303-310. doi: 10.11607/jomi.2869.

[7] Kim, Y., Oh, T., Misch, C., \& Wang, H. (2004). Occlusal considerations in implant therapy: clinical guidelines with biomechanical rationale. Clinical Oral Implants Research, 16(1), 26-35. doi: 10.1111/j.16000501.2004.01067.x.

[8] Komiyama, O., Lobbezoo, F., De Laat, A., lida, T., Kitagawa, T., Murakami, H., \& Kawara, M. (2012). Clinical Management of Implant Prostheses in Patients with Bruxism. International Journal of Biomaterials, 2012 369063. doi: $10.1155 / 2012 / 369063$

[9] Pavlenko, O. V., Bida, V. I., Doroshenko, O. M., \& Sirenko, O. F. (2012) Elektromiohraphichna otsinka funktsionalnoi aktyvnosti zhuvalnykh miaziv u patsientiv z ortopedychnymy konstruktsiiamy z oporoiu na implantaty [Electromyographic activity of masticatory muscles of patients with orthopedic constructions fixed on implants]. Sovremennaya stomatologiya, 3(62), 131-134 [in Ukrainian].

[10] Uram-Tuculescu, S., Cooper, L., Foegeding, E., Vinyard, C., De Kok, I., \& Essick, G. (2015). Electromyographic Evaluation of Masticatory Muscles in Dentate Patients Versus Conventional and Implant-Supported Fixed and Removable Denture Wearers - A Preliminary Report Comparing Model Foods. The International Journal Of Prosthodontics, 28(1), 79-92. doi: 10.11607/ijp.3931.

\section{Information about authors:}

Doroshenko O. M., MD, PhD, DSci, Professor, Director

of the Institute of Dentistry, Shupyk National Medical Academy

of Postgraduate Education, Kyiv, Ukraine.

http://orcid.org/0000-0002-5252-6640

http://www.researcherid.com/rid/C-7946-2016
Sirenko O. F., MD, PhD, Associate Professor, Department of Dentistry, Shupyk National Medical Academy of Postgraduate Education, Kyiv, Ukraine.

http://orcid.org/0000-0002-7923-8534

http://www.researcherid.com/rid/J-6760-2016

\section{Відомості про авторів:}

Аорошенко 0. М., А-р меА. наук, професор, Аиректор Інституту стоматології, Національна меАична академія післядипломної освіти імені П. ^. Шупика, м. Київ, Україна.

Сіренко О. Ф., канА. меА. наук, Аоцент каф. стоматології, Національна медична академія післядипломної освіти імені П. ^. Шупика, м. Київ, Україна.

\section{Сведения об авторах:}

Аорошенко Е. Н., А-р меА. наук, профессор, Аиректор Института стоматологии, Национальная медицинская академия последипломного образования имени П. А. Шупика, г. Киев, Украина.

Сиренко А. Ф., канА. меА. наук, Аоцент каф. стоматологии, Национальная медицинская академия последипломного образования имени П. ^. Шупика, г. Киев, Украина.

Конфлікт інтересів: віАсутній.

Conflicts of Interest: authors have no conflict of interest to declare.

Надійшло Ао редакції / Received: 04.04.2017

Після Аоопрацювання / Revised: 10.04.2017

Прийнято Ао Аруку / Accepted: 12.04.2017 